\title{
Destination or Decision Caused by Promotional Mix
}

\author{
Iwan Budiherwanto \\ Politeknik "Api" Jogjakarta, Indonesia \\ E-mail: iwan_b@poltekapi.ac.id \\ Tri Wahyudi \\ Politeknik "Api" Jogjakarta, Indonesia \\ E-mail: triwa_h@poltekapi.ac.id \\ Rudy Pramudyanto \\ Politeknik "Api" Jogjakarta, Indonesia \\ E-mail: rudy_p@poltekapi.ac.id
}

Received: Dec. 2, 2018 Accepted: Dec. 20, 2018 Online published: Jan. 15, 2018

doi:10.5296/ijhrs.v9i1.13980ＵRL: https://doi.org/10.5296/ijhrs.v9i1.13980

\begin{abstract}
This study aims to analyze the media advertising, individual sales, sales promotions and public relations to the decision to stay at the hotel. The population and sample are hotel visitors, the census sampling technique used to determine 70 respondents. This type of research is descriptive exploratory using primary and secondary data. The results of this study are advertising media, individual sales, sales promotions and public relations contributing to increasing hotel visitors.
\end{abstract}

Keywords: advertising media, individual sales, sales promotion, public relations and visiting decisions

\section{Background of the Study}

Yogyakarta, besides known as city of fight, cultural and educational center, it is also famous due to its natural and cultural enchantment. Until nowadays, Yogyakarta is still a famous tourism destination both domestically and overseas. Besides that, Yogyakarta is also called as Famous Tourism Object Destination because of various object enchantment and tourism attractiveness which have been supported by various facilities to support the tourism objects, 
such as accommodation, restaurant/food stall, telecommunication, amusement park, souvenir stall, and so on.

Industries in the form of hotel and accommodation have challenges in overcoming competition from various hotel services in order to improve their selling. The condition of such market makes companies to adapt to survive from the competition.

Promotion is one of element of activities determining the success of a company. A company's promotion is not only to get profit but also to introduce product or services to potential consumers. One of the promoting strategies to attract the costumers' interest toward the offered products. The promotion is expected to take over, defend, and improve the volumes of selling.

Target promotion used by hotel industries is to improve visitors, known as promotion distribution. It is called so because it consists of some types of common promotions of a company to adjust the types of promotion used by other promotion distribution. It is grouped into four elements: advertising, personal selling, sales promotion, and public relation.

Hotel Eclipse is two star hotel located $3 \mathrm{~km}$ away from the center of Yogyakarta, on Jl. Prawirotaman. Number 35, Brontokusuman, Mergangsan, Yogyakarta, Special Region of Yogyakarta. The location is famous as foreign kampong or tourist kampong in Yogyakarta. It is called so because the atmosphere in the area has some hotels/accommodations, restaurants/cafes dominated by foreign tourists. The nuance of the downtown kampong, started from transportation crowds until the greetings of society whom speak English. About 50 hotels and accommodations with their unique buildings' designs, started from classic Java until current nuanced hotels, exist in this area.

Location factor is relevant with the focus of the target market of the Hotel, the foreign tourists. However, it is not limited only for foreign tourists but also the domestic ones, especially in low season period. Realizing this situation, the competition and challenge faced by management of the hotel will not be easy.

Based on the observation done by the author in Hotel Eclipse Yogyakarta, the structured and continuous promotions are needed by the hotel to get new consumers, especially in low season period and to build hotel credibility.

Hotel Eclipse Yogyakarta needs serial and continuous promotion activities and holds interesting events to get new consumers. Some promotion media have been published and the events as the media to support selling have been followed, but the results are not maximal. The research has purpose to analyze advertising media, personal selling, sales promotion, and public relation with decision to stay in the hotel.

\section{Review of Related Literature}

\section{Advertising}

Advertising is non-individual communication, with certain amount of budget, through media done by companies, non-profit organization, and individuals. It is a form of promotion mostly 
used by companies in promoting their products. According to Widiana (2010) "Advertising is a form of indirect communication, based on information about the strength and weakness points of the product, arranged to trigger happiness which will change someone's mind to buy."

\section{Personal Selling}

Philip Kotler, quoted by Saladin (2006), face to face personal selling is defined as: "Personal selling is face to face interaction, answering questions and procuring ordersales". It means "face to face personal selling is an oral presentation in a conversation with one or more potential buyers with purpose to trade."

H. Buchori Alma (2005 : 183 ) definespersonal sellingas : "Personal selling is oral presentaion in a conversation with one or more prospective customer for the purpose of making sales". It means "Personal selling is an expression orally to face a candidate or candidates of buyers by intention to create selling.

\section{Sales Promotion}

Nembah F. Hartimbul Ginting, 2011:206) "Sales promotion is a short term stimulus to motivate buying". If advertisement is compared to sales promotion, then advertising has more reasons to buy, while promoting gives reason to buy at that time. Sales promotion is a direct persuasion to use the products as manageable incentives to trigger product purchasing immediately to improve the numbers of product purchased by customers.

The key of sales promotion is current day selling, by explaining the actual product, the decreasing price, or anything. Many types of sales promotion are included into temporal price degression through discount or coupons, or gifts and bonus given to the candidates of buyers so it makes sales promotion as promising meant of promotion. The aspect of sales promotion is also push the current day product instead of tomorrow's product. A certain sales promotion encourages actual thing so the promotion is oriented to change immediate consumers' buying.

\section{Public Relation}

J. C. Seidel, "Public relation is the continuing process by which menagement endeavors to obtain goodwill and understanding of its customers, its employers, and the public at large ; inwardly through self analysys and corrections, inwardly through all means of expressions." It means "Public relation is a continuous process from managerial efforts to get good commitment and attention from the customers, employees, and general society; in the inside it is done by analyzing and revising for themselves, outside by using questions.

According to Nembah F. Hartimbul Ginting (2011:209), public relation and publicity are defined "Important mass promoting meant purposed to create good relationship from various companies by getting good publicity and images and solving negative things:.

Creating good relationship to society is an obligation to do by companies because it will influence the point of views of society toward a company.

Public relation is defined as managerial function to give judgment about society's attitudes, policy identity, and individual or organizational procedures demanded by society and doing 


\section{Macrothink}

action program to get definition and society's acknowledgement. Public relation is a part of one department with responsibility to listen and collect any criticisms, complaints, or suggestions from society. Public relation is not a promoting meant, but it is important to adjust the organization to social needs.

\section{Staying Decision}

Facing this globalization era, in which can be experienced anywhere, the hotel industries' competition are strict, it needs applicable business strategy as weapon to win over the market, and to improve hotel rooms' selling. The management of hotel in using its sources tries to improve the selling of hotel's rooms, it cannot be separated from strategy designs determined by the hotel. Room selling strategy through promotion cannot be separated from whole hotel's efforts based on its mission and vision. The strategy through marketing is part of operational concept design to fulfill demand and needs and also the purposes of the guests to stay or currently to be staying in the hotel. Besides that, other concepts supporting the strategy of hotel business is marketing and human source developing concepts.

Other ways to optimize the level of staying in starred hotels is by implementing room implementation strategy. In this case, the strategy is important to face a situation how to fulfill the empty rooms. Usually in different days and times in whole year, a room will be rent variously according to some considerations.

\section{Theoretical Frameworks}

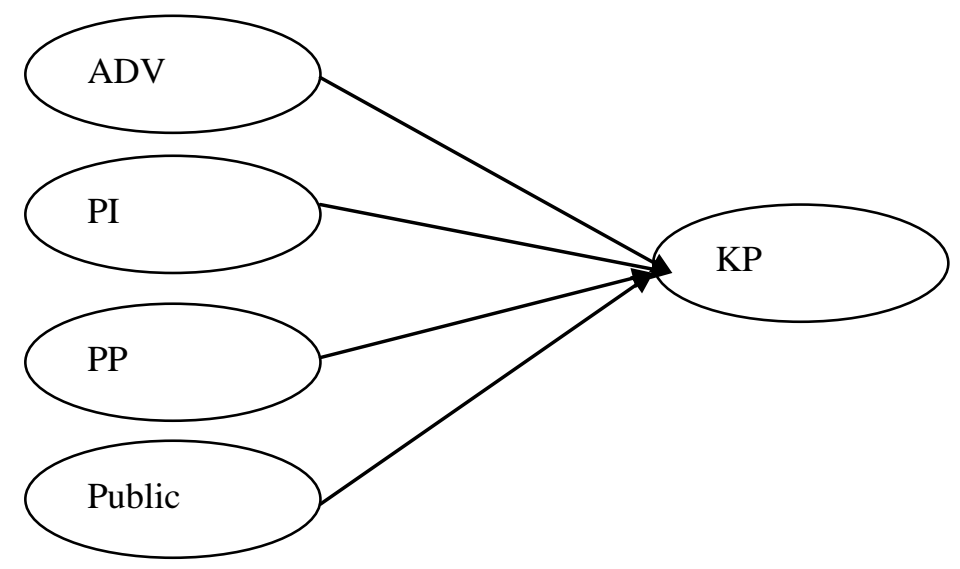

\section{Methodology}

This case study explores information from the object then is quantified as the answers upon the investigated hypothesis.

\section{Population and Sample}

The population and sample are the visitors of Hotel Eclipse Yogyakarta with numbers of respondents 70 by using census. The use of census is to clarify the visitors staying or those only spending time in restaurant. 
Operational Variable

Widiana (2010) advertisement is an indirect communication form based on information related to strength and benefit of certain product, arranged so to trigger joys, and to change an individual's mindset to buy it. Advertising variable is measured by using indicators from brochure, ballyhoo, the impression of advertisement, and the role of advertisement. Kotler (2002) direct selling interacts with buyers to create or defend the relationship of mutual trading for both parties. The indicators of direct selling are building up impression and formulating strategies. Nembah Ginting (2011) "sales promotion is a short term stimulus to motivate buying. The indicators are using performance, gift coupons, and bonus. Ginting (2011), mass promoting meant is important, addressed to build up good relationship to companies by gaining publicity and good images. The measuring variable of public relation is measured by using consumers' services and reputation. Mustafid \& Gunawan (2008) the decision to stay is one reason about how consumers determine their choice toward the purchase of a product based on their needs and expectation, so it will trigger satisfaction or dissatisfaction toward the products, influenced by some factors such as family, price, experience, and quality of the products. The indicators are recognizing needs, seeking information, evaluating alternatives, determining the purchasing, and behaving after purchasing.

\section{Findings}

Table 1. The Calculation of Multiple Linier Regression

\begin{tabular}{c|c|c|c}
\hline Coefficient & B & t & Sig t \\
\hline Constanta & 14,222 & 4,330 &, 000 \\
\hline Working environment $\left(\mathrm{X}_{1}\right)$ &, 413 & 3,464 &, 001 \\
\hline Working satisfaction $\left(\mathrm{X}_{2}\right)$ &, 268 & 2,956 &, 005 \\
\hline F & & \multicolumn{2}{|c}{49,198} \\
\hline Sig F & \multicolumn{2}{c}{0,000} \\
\hline $\mathrm{R}^{2}$ & & 0,658 \\
\hline
\end{tabular}

Constanta 14,222 (positive) states that positive influences from independent variable, working environment $\left(\mathrm{X}_{1}\right)$, and working satisfaction $\left(\mathrm{X}_{2}\right)$, then the dependent variable working performance $(\mathrm{Y})$ is stated to have positivechanges. The coefficient of working performance regression variable $\left(\mathrm{X}_{1}\right)$ is 0,413 (positive), it means the variable of working environment positively influencing toward employees' performance. The better working environment is created and used by the management, the employees' performance in Ros in Hotel Yogyakarta is better also.

The coefficient of working satisfaction regression variable $\left(\mathrm{X}_{2}\right)$ is 0,268 (positive), it means the variable positively influencing employees' performance. The better the performance, then the management will more appreciate to the employees whom have done their task and whose well responsibility.

Based on the analysis, it can be seen the variable of working environment has the most dominant influences compared to working satisfaction, so the management will be pleasured by the results of employees' performance and without doubt will give appropriate award to 
the achievers and employees' with best performance.

\section{Hypothesis}

The t-test for working environment variable is gained t-calculated score $=3,464$. Meanwhile,score of t-table $(\alpha=0,05, \mathrm{df}=\mathrm{n}-2=51-2=49)$ is 2,009 . The significant level $=0,001<\alpha=0,05$ (on figure $\alpha=0,025$, because it is located in both sides of the curve). By using such criteria, then $\mathrm{H}_{0}$ is deniedand $\mathrm{H}_{2}$ is accepted.Working satisfaction variable gains $\mathrm{t}$-calculated $=2,956$. Meanwhile, score of t-table $(\alpha=0,05, \mathrm{df}=\mathrm{n}-2=51-2=49)$ is 2,009 , the significant level $=0,005<\alpha=0,05$ (on the figure $\alpha=0,025$, because it is located in both sides of the curve). Therefore, $\mathrm{H}_{0}$ is deniedand $\mathrm{H}_{\mathrm{a}}$ is accepted.

The significant level $=0,000<\alpha=0,05$. Therefore, $\mathrm{H} 0$ is deniedand $\mathrm{Ha}$ is accepted. Score of $\mathrm{F}$ table $(\alpha=0,05$; df numerator $=\mathrm{k}=2$; df denominator $=\mathrm{n}-\mathrm{k}-1=51-2-1=48)$ is $\mathbf{1 , 6 1}$.

The coefficient score of the determinant $\left(\mathrm{R}^{2}\right)$ is 0,658 or $65,8 \%$. It means that the variables $\mathrm{X}_{1}$, and $\mathrm{X}_{2}$, simultaneously influence in same quantity $65,8 \%$ toward Y. Meanwhile, the rest is $34,2 \%$ influenced by other uninvestigated variables.

\section{Discussion}

From the first hypothesis, it shows the existence of positive and significant influences between working environment toward employees' performance. Therefore, it can be said if working environment gives harmonious, joyful, secure, and peace situations will influence toward the quality of employees' performance.

According to (2000:151) "working environment is anything around employees in which can influence in their working, covering from lighting, noise controlling, clarity management of the working place, and security management. Working environment has great influences toward the operational of companies. Good working environment and is able to satisfy the employees can motivate their spirits to work.

This second hypothesis test shows the existence of positive and significant influences toward working satisfaction toward employees' performance so it can be concluded that working satisfaction is common attitude owned by employees in which closely related to rewards, for them, to be believed to get after a sacrifice (Robbins, 2001). As stated by As'ad (2004), working satisfaction is "an individual's feeling toward profession". It means that the conception of working satisfaction is seen from as interacting result between human and the working environment. Basically, an individual working will feel comfortable and have high loyalty toward company if in his works gain working satisfaction based on what he demands.

The third hypothesis test shows positive and significant influences of working environment and working satisfaction variables simultaneously toward employees' performance in Ros Hotel Yogyakarta. An employee will feel comfortable, safe, peace, and happy and do not feel being burden each time he does his tasks and responsibilities in working when they get or have harmonious environment with working satisfaction. According to Rivai and Basri $(2005 ; 50)$ explain that performance is result or level of success of someone from whole one period in doing his tasks compared to various possibilities, such as performance, target, or 
any preliminary determined and agreed criteria.

From those two investigated independent variables, working environment is the most influencing toward employees' performance. It really makes sense because working environment is they main key of a company's success. When working environment is good an able to satisfy the employees, it can motivate the improvement of working spirit so the employees of the hotel will feel satisfied and motivated to improve their quality in working.

\section{Conclusion}

There are positive and significant influences between working environment variables toward employees' performance in Ros In Hotel Yogyakarta. There are positive and significant influences between working satisfaction toward employees' performance in the Hotel. There are similar influences between working environment and working satisfaction toward employees' performance of the hotel. Working environment variable has the greatest influences compared to working satisfaction variable toward employees' performance in the Hotel. It is based on the data analysis showing the output of working environment is $0.413>$ output of working satisfaction, 0.268 .

\section{Suggestion}

The influence of working environment toward employees' performance in Ros In Hotel Yogyakarta needs improvement and renewal in terms of hotel nuances because the environments of the hotel are comfortable, safe, beauty, and having new and modern facility to improve the quality and quantity of employees' performance.

The influence of working satisfaction toward employees' performance in the Hotel needs to be more intensive in communicating between employees and the leader so the vision and mission can be achieved well, and always give reward to achiever both financially or non-financially, to trigger better working performance from other employees, and to improve guest services both with purpose to stay or only visit in the Hotel.

To realize them, all managerial parties, periodically need to struggle to change working environment so the display and working situation will not make the employees boring, to give periodically appreciation and routine to achievers so it will make the employees motivated to work and to improve guest service, so the hotel will be more developed well as expected by management.

\section{References}

Arep, I., \& dan Tanjung, H. (2002). Manajemen Sumber Daya Manusia. Penerbit Universitas Trisakti, Jakarta.Manajemen Sumber Daya Manusia

As'ad, M. (2004). Psikologi Industri, Seri Umum. Sumber Daya Manusia. Yogyakarta: Liberty.

Dessler, G. (2005). Manajemen Sumber Daya Manusia. PT. Indeks, Jakarta.

Gomes, F. C. (2003). Manajemen Sumber Daya Manusia. Penerbit ANDI, Yogyakarta. 


\section{Macrothink}

International Journal of Human Resource Studies

ISSN 2162-3058 2019, Vol. 9, No. 1

Hasibuan, M. S. P. (2007). Manajemen Sumber Daya Manusia (Edisi Revisi). PT. Bumi Aksara, Jakarta.

Kreitner, R., Kinicki, A., \& Cole, N. D. (2006). Fundamentals of Organizational Behaviour: key concepts, skills \& best practices. Special Materials Services, Manitoba Education.

Mangkunegara, A. A. P. (2002). Manajemen sumber daya manusia perusahaan. Remaja Rosdakarya.

Mangkunegara, A. A. P. (2004). Manajemen Sumber Daya Manusia Perusahaan. PT Remaja Rosdakarya, Bandung.

Mangkunegara, A. A. P. (2011). Manajemen Sumber Daya Manusia Perusahaan. PT Remaja Rosdakarya, Bandung.

Marthis, R. L., \& Jackson, J. H. (2006). Human Resource Management: Manajemen Sumber Daya Manusia. Terjemahan Dian Angelina. Jakarta: Salemba Empat.

McShane, S. L., \& Mary, A. V. G. (2008). Organization Behavior, 4ed. New York: McGraw-Hill Companies, Inc.

Nurulita. (2010). Manajemen Sumber Daya Manusia I. Penerbit LepKhair.

Prawirosentono, S. S. (1999). Kebijakan Kinerja Karyawan.Yogyakarta : BPFE.

Rivai, V. (2005). Manajemen Sumber Daya Manusia untuk Perusahaan dari Teori ke Praktek. PT. Raja Grafindo Persada, Jakarta.

Robbins, S. P. (2001). Perilaku Organisasi: Konsep Kontroversi, Aplikasi. Jilid I Terjemahan., PT. Indeks Kelompok Gramedia, Jakarta.

Sedarmayanti. (2001). Sumber Daya Manusia dan Produktivitas Kerja. CV. Mandar Maju, Bandung.

Sugiyono. (2004). Metode Penelitian Bisnis. Alfabeta, Bandung.

Susilo, M. (2000). Manajemen Sumber Daya Manusia. Edisi Ketujuh, BPFE, Yoyakarta.

Zainun, B. (2001). Manajemen Sumber Daya Manusia Indonesia. PT. Toko Gunung Agung, Jakarta.

\section{Copyright Disclaimer}

Copyright for this article is retained by the author(s), with first publication rights granted to the journal.

This is an open-access article distributed under the terms and conditions of the Creative Commons Attribution license (http://creativecommons.org/licenses/by/4.0/). 